\title{
Climate change will exacerbate California's insect pest problems
}

by John T. Trumble and Casey D. Butler

\section{The elevated carbon dioxide}

concentrations and increasing

temperatures associated with

climate change will have substantial

impacts on plant-insect interac-

tions, integrated pest management

programs and the movement of

nonnative insect species into Cali-

fornia. Natural ecosystems will also

be affected by the expected changes

in insect diversity. Many insects will

alter how much they eat in response

to changing plant nutrition. Also, we

can expect increased problems with

many pest insects as they develop

more rapidly in response to rising

temperatures. If we hope to maintain

sustainable agro-ecosystems and

preserve native species in our natural

ecosystems, we need to begin pre-

paring now for the challenges of our changing environment.

Climate change is occurring. While some people may find controversy regarding the cause, there is no doubt that carbon dioxide levels, temperatures and ultraviolet levels are increasing (IPCC 2007). Most global climate models predict that rainfall patterns will change and that storms will increase in severity (Hadley Centre 2007). The cumulative effects of these changes on plants and insects in California's agricultural and natural ecosystems are likely to be substantial.

Rising carbon dioxide will increase the carbon-to-nitrogen balance in plants, which in turn will affect insect feeding, concentrations of defensive chemicals in plants, compensation responses by plants to insect herbivory, and competition between pest species (Coviella and Trumble 1999). Temperature increases already have caused changes in species diversity and distribution. For example, the mountain pine beetle, a major forest pest in the
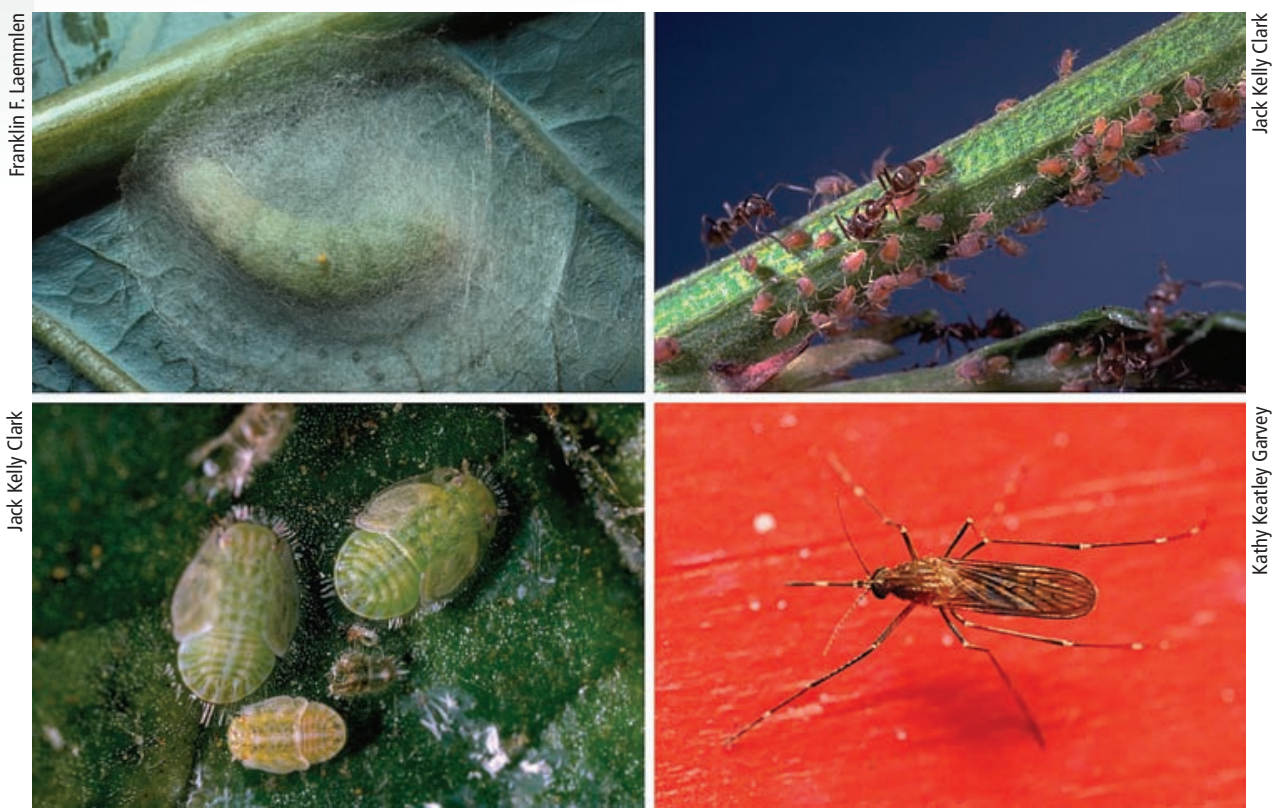

Climate change will fundamentally alter our relationship with pest insects. Top left, the cabbage looper ate $20 \%$ more leaf area when lima beans were grown at high carbon-dioxide concentrations. Top right, Argentine ants (shown tending aphids) out-compete native ants at higher temperatures. Bottom left, the potato psyllid did not establish itself on earlier attempts, but its 1999-2000 migration into California was successful. Bottom right, mosquitoes, which carry dengue fever and malaria, emerge smaller when they breed in warmer water and must blood-feed more frequently.

United States and Canada, has extended its range northward by approximately 186 miles (300 kilometers) with the temperature increase of approximately $3.5^{\circ} \mathrm{F}\left(1.9^{\circ} \mathrm{C}\right)$ (Logan and Powell 2001). Additional changes in climatic boundaries and agro-ecosystem borders will have significant implications not only for the population dynamics of native pests, but also for the occurrence and severity of invasive species (Bale et al. 2002). Even patterns of outbreaks for arthropod pathogens such as fungi are expected to vary (Stacey and Fellowes 2002). Arthropod-borne human diseases such as dengue and malaria will likely increase (Juliano and Lounibos 2005).

By some estimates, agricultural productivity in Africa, Asia and Latin America is expected to decrease by as much as $20 \%$, with less developed countries suffering the greatest negative effects (IPCC 2007). In California, we can expect that current insect pests will extend their ranges into new areas, and that a variety of new insect pests will appear. All of these climate-driven changes present challenges and opportunities for sustainable agricultural programs based on integrated pest management (IPM). If California's food production is to keep pace with growing demand, we will need new cultivars, major changes in IPM programs, increased funding and improved response times to new pest outbreaks.

In this brief review we cannot cover all of the potential impacts of climate change. We will not discuss the predicted changes in rainfall, which are rather variable and entail an increase for Northern California and a decrease for Southern California (Hadley Centre 2007). Also, while the interactions of droughts, increasing temperatures, storms and other possible factors are likely to be important, space limitations preclude a detailed analysis. We focus instead on the two major climatechange variables that have the strongest documentation: increasing levels of atmospheric carbon dioxide and increasing temperatures.

\section{Elevated carbon dioxide}

One of the most studied aspects of climate change is the effect of increasing concentrations of carbon dioxide 
TABLE 1. Examples of how increasing atmospheric carbon dioxide affects plant-insect interactions

\begin{tabular}{ll}
\hline \hline Increasing atmospheric carbon dioxide leads to: & Reference \\
\hline Increasing ... & \\
Food consumption by caterpillars & Osbrink et al. 1987 \\
Reproduction of aphids & Bezemer et al. 1999 \\
Predation by lady beetle & Chen et al. 2005 \\
Carbon-based plant defenses & Coviella and Trumble 1999 \\
Effects of foliar applications of $B$. thuringiensis & Coviella and Trumble 2000 \\
Decreasing ... & \\
Insect developmental rates & Osbrink et al. 1987 \\
Response to alarm pheromones by aphids & Awmack et al. 1997 \\
Parasitism & Roth and Lindroth 1995 \\
Effects of transgenic $B$. thuringiensis & Coviella et al. 2000 \\
Nitrogen-based plant defenses & Coviella and Trumble 1999 \\
\hline
\end{tabular}

on plants (table 1). Plants consist primarily of carbon, and elevated carbon dioxide levels allow them to grow more rapidly because they can assimilate carbon more quickly. Greenhouse growers have known this for decades, and many add carbon dioxide to encourage plant growth.

Similarly, because carbon dioxide increases the photosynthetic rates of most crop plants, scientists initially thought that increasing carbon dioxide would be a panacea for the world's food supply (LaMarche et al. 1984). In addition to growing more quickly, many crop plants would become more drought-tolerant. This is because the openings in the leaves (stomata) that let carbon dioxide in also let water vapor out, and if there is more carbon dioxide, then the stomata do not need to be open as much.

Crop yields. Under conditions of elevated carbon dioxide, LaMarche et al. (1984) suggested that the bigger, more drought-tolerant plants which developed would be expected to produce better yields even when conditions are harsh. Unfortunately, this optimistic prediction has not proven accurate. One reason that yields have not increased is that insects also eat more when plants are grown in elevated levels of carbon dioxide. Early research in California demonstrated that while lima beans (Phaseolus lunatus) did photosynthesize better and grow more rapidly in higher concentrations of carbon dioxide, their primary pest, the cabbage looper (Trichoplusia ni), also ate about $20 \%$ more leaf area (fig. 1).

This occurred because the leaves contained about $28 \%$ less nitrogen in comparison to plants grown in ambient levels of carbon dioxide. Insects are animals that must have nitrogen to develop. Because there was less nitrogen in the leaves grown in elevated levels of carbon dioxide, the cabbage loopers' response was to eat more leaf area in order to get the same amount of this critical nutrient. This effect of increased feeding has now been shown for many insect groups such as butterflies, beetles, moths and grasshoppers (Coviella and Trumble 1999). Other possible reasons for a lack of accelerated crop growth include an adaptation to elevated carbon dioxide that slows photosynthesis (Hollinger 1987) and evidence that increased temperatures will reduce the productivity of plants in tropical and subtropical climates (IPCC 2007).

Plant defenses. This abundance of carbon and shortage of nitrogen leads to other major changes in the plant that can further affect insects. Many plants have two types of chemical defenses that reduce or stop insect feeding. One group is carbon-based compounds (such as phenolics and tannins) that tend to slow insect growth, often by binding with proteins to reduce the insect's ability to digest the food. Cotton is a good example of a plant with phenolics that can reduce insect feeding. Elevated carbon dioxide levels allow many plant species to greatly increase their carbon-based defenses.

A second group of common plant defenses is nitrogen-based compounds (such as alkaloids and cyanogenic glycosides) that either act as toxins and kill the insects or act as repellents and make the plants unpalatable. For example, potatoes and plums are plants containing defensive compounds based on nitrogen. Elevated carbon dioxide levels often reduce concentrations of these nitrogen-based defenses.
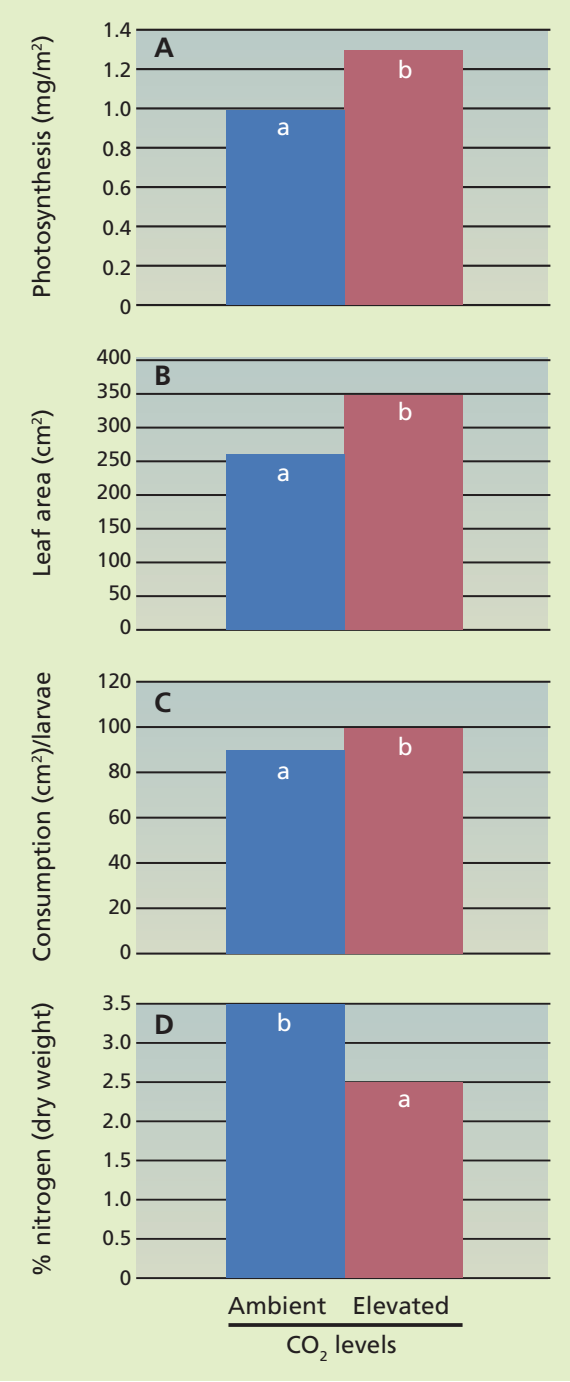

Fig. 1. (A) Photosynthetic activity, (B) leaf area, (C) leaf area consumption by cabbage looper larvae and (D) nitrogen content of lima bean plants grown in elevated $(900 \mathrm{ppm})$ and ambient (385 ppm) carbon dioxide (Osbrink et al. 1987). Different letters above bars indicate significantly different values $(P<0.05)$.

The trade-off between carbon- and nitrogen-based plant defenses will have many potentially far-reaching effects on insect feeding. In natural ecosystems that have limited nitrogen availability, plants may have lower levels of nitrogen-based toxins and so be subject to greater insect damage. In agricultural systems, however, growers typically manipulate the availability of nitrogen, which can affect the concentrations of these defensive compounds. For example, when cotton plants were grown with 2.5 times the normal amount of nitrogen fertilizer, the concentrations of carbon-based defenses dropped dramatically (fig. 2). 
Transgenic plants and insecticides. Interestingly, such changes have important implications for the use of certain transgenic plants that are resistant to insects. Currently, the most commonly used genetic modification in corn and cotton is the addition of proteins from the bacterium Bacillus thuringiensis (Bt). These proteins are nitrogen-based defenses that have a major impact on several common insect pests, greatly reducing yield losses. In our studies, growing these transgenic plants in elevated carbon dioxide resulted in a nearly $25 \%$ reduction of the expression of these proteins (fig. 3). This reduction allowed some beet armyworms (Spodoptera exigua) to survive on these plants, which would likely lead to the rapid selection of pest populations resistant to these proteins.

Again, growers can overcome this effect by adding additional nitrogen. However, this is an expensive proposition and may also increase the nitrogen runoff from fields, causing problems for adjacent aquatic systems. Because most commercial fertilizers are manufactured from petroleum, an increase in nitrogen use would also cause an undesirable increase in carbon dioxide released into the atmosphere. We suspect that new methods of making transgenic plants, such as linking expression to mitochondria, ultimately will be employed to overcome this problem.
In contrast to insect-resistant transgenic plants, some insecticides that are applied to plant foliage will likely work better in elevated carbon dioxide. As noted earlier, insects eat more leaf area when plants are grown in elevated carbon dioxide. This means that chewing insects that eat more would get a larger dose of any toxin on the plant. We tested this hypothesis with spray applications of an organically acceptable B. thuringiensis preparation, many of which are widely available. Not surprisingly, the insects that ate more leaf area received a greater dose of the toxin and died significantly faster and in higher numbers (Coviella and Trumble 2000). Thus, the selection of pesticides that act as stomach poisons may become an increasingly important strategy for insect control as carbon dioxide levels rise.

\section{Increased temperatures}

Temperatures in most regions of the world are increasing, and there are already indications that insects and plants are responding (table 2, page 76 ). These temperatures are not just the result of warmer summer days but also of fewer cold days, cold nights and frosts (IPCC 2007). In coastal California, average temperatures are predicted to increase by up to $10^{\circ} \mathrm{F}\left(5^{\circ} \mathrm{C}\right)$ inland and $5^{\circ} \mathrm{F}\left(2.5^{\circ} \mathrm{C}\right)$ along the coast in this century (Hadley Centre 2007). In California, we should plan on: (1) the range expansions of insects that are already here, (2) the arrival of more

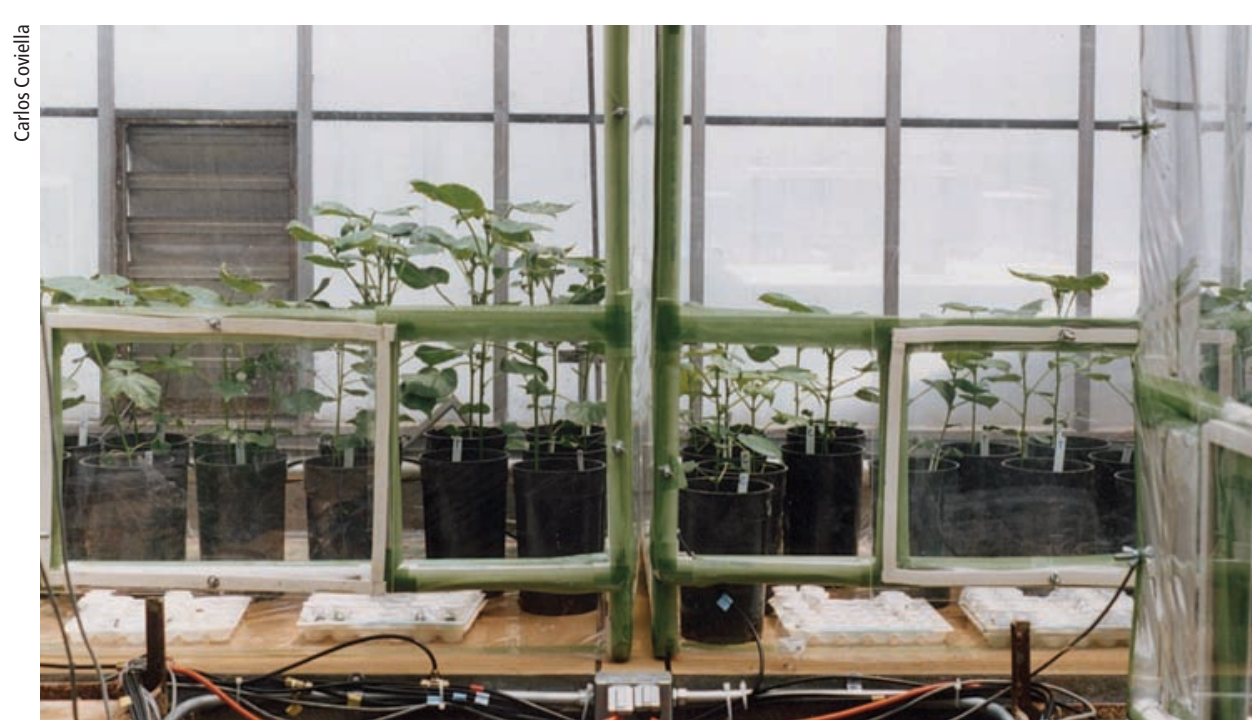

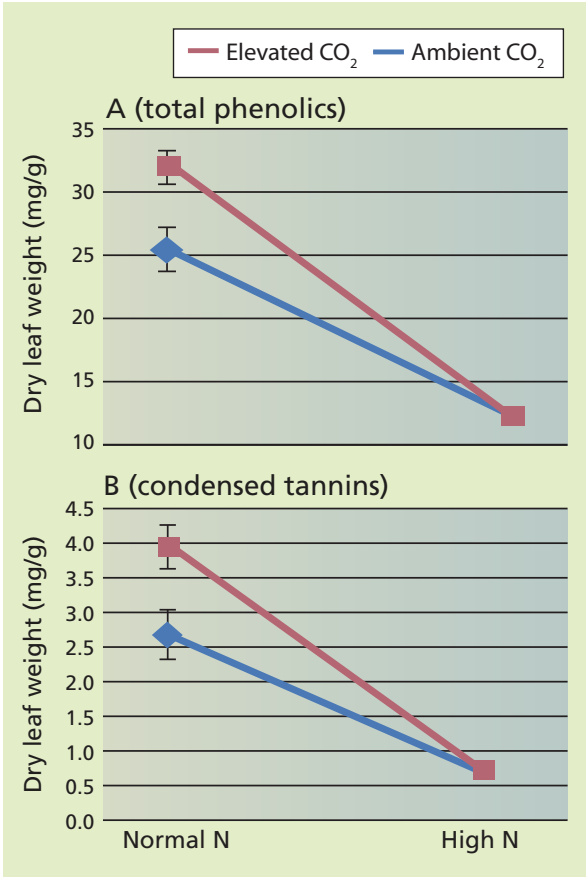

Fig. 2. Increased nitrogen ( $N$ ) fertilization led to reduced production of carbon-based defensive compounds in cotton grown in elevated $(900 \mathrm{ppm}$ ) versus ambient (385 ppm) carbon dioxide for (A) total phenolics and (B) condensed tannins (Coviella et al. 2002). Values are significantly different at normal nitrogen fertilization levels. Data are presented as interaction plots following a $2 \times 2$ factorial ANOVA with least square means tables calculated for all significant interactions.

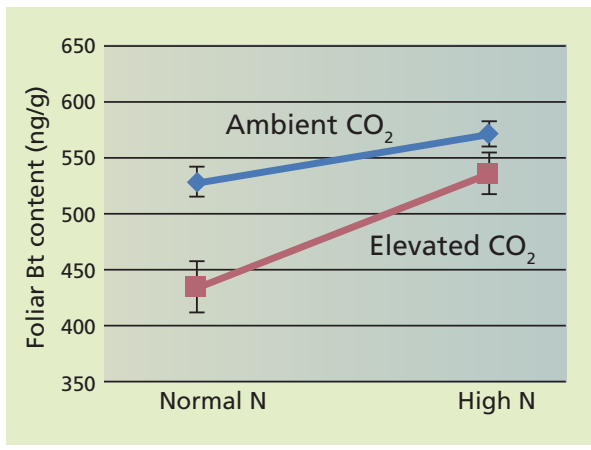

Fig. 3. Interactions of ambient (385 ppm) and elevated (900 ppm) carbon dioxide and nitrogen fertilization on expression of Bacillus thuringiensis $(\mathrm{Bt})$ proteins in cotton $(\mathrm{ng} / \mathrm{g}$ = nanograms/gram) (Coviella et al. 2000). Values for foliar Bt content are significantly different for normal (1x) and high (2x) nitrogen fertilization levels. Data are presented as an interaction plot following a $2 \times 2$ factorial ANOVA with contrast analyses calculated for all significant interactions.

Plants grown at elevated carbon dioxide have lower nitrogen levels in the leaves, so insects must eat more to get the same amount of nutrient. In this chamber study, insects eating plants treated with Bacillus thuringiensis received a higher dose of the toxin as well, and died at significantly higher rates. 
new insect pests and (3) changes in ecosystems that will allow some insect species to reach dramatic new population levels while forcing other species into extinction.

Range expansion. In the Northern Hemisphere, insect populations are already migrating northward. Even though regional temperatures have increased by only $3^{\circ} \mathrm{F}$ to $4^{\circ} \mathrm{F}\left(2^{\circ} \mathrm{C}\right)$ in the past 25 years, rather dramatic shifts of 185 miles in range have been reported for the green stinkbug (Acrosternum hilare) in England and Japan. Likewise, the Edith's checkerspot butterfly (Euphydryas editha) is expanding its population northward in the United States while declining at the southern end of its range in Mexico (Parmesan 2006). In the past 15 years, the mountain pine beetle (Dendroctonus ponderosae), a destructive pest of pine trees, has extended its range more than 180 miles northward (Logan and Powell 2001). This movement has allowed adults at the northern extent of the beetles' range to cross through Pine Pass to reach the east side of the Rocky Mountains. These migrations are not unexpected, as similar range shifts have been observed in the fossil insect record when climatic conditions changed (Elias 1994).

One reason for such range expansions is a change in frost patterns (Fleming and Volney 1995; IPCC 2007). As temperatures increase, the frequency of spring frosts declines and the resulting extended frost-free periods increase the duration and intensity of insect outbreaks. Growers can also be expected to take advantage of the changing climate by planting earlier. These plants will then be available for crop-infesting insects, allowing insect populations to get an even quicker start and potentially add additional generations during a typical growing season. For many crop pests, this means much bigger populations by the end of the season. For these reasons, the Intergovernmental Panel on Climate Change (a scientific body set up by the World Meteorological Organization and the United Nations Environment Program) lists increasing insect outbreaks as "virtually certain" (IPCC 2007).

New pests. New insect species arrive frequently in California, primarily due to the rapid movement of people and goods. However, increasingly warmer temperatures mean that insects that previously could not survive here can now thrive. For example, while a destructive pest known as the potato psyllid migrated into California on several occasions in the 20th century, those populations usually lasted only for a year. Cool temperatures during the winter forced this insect to retreat to Mexico and the southernmost tip of Texas. However, the potato psyllid migrated into California again in 1999 or 2000, and has since established large, year-round populations as far north as Ventura County that have persisted for the last 7 years. The tomato, potato and pepper industries have suffered substantial losses as a result (Liu and Trumble 2007).

Ecosystem changes. Warmer temperatures will benefit some insect species over others. In our studies, even a $5^{\circ} \mathrm{F}$ to $6^{\circ} \mathrm{F}\left(3^{\circ} \mathrm{C}\right)$ increase in average summer
Because insect development is more rapid at higher temperatures, populations will develop faster and crop damage will occur more rapidly than currently expected.

temperatures in Southern California would reduce offspring production by about $90 \%$ for an important beneficial wasp, the common parasite Cotesia marginiventris (C.D. Butler and J.T. Trumble, unpublished data). This seemingly minor temperature increase is therefore likely to eliminate populations of this parasite in many interior valleys. The loss of this insect could lead to increased damage from some caterpillar species, and would likely result in increased pesticide applications.

On the other hand, higher temperatures will favor some agricultural and urban pests. Argentine ants (Linepithema humile), which have already expanded throughout Southern and Central California, are better competitors against native ant species at higher temperatures (Dukes and Mooney 1999). As temperatures rise, this pest will likely spread farther north, displacing more native ant species. The spruce budworm (Choristoneura fumiferana) will also benefit from warmer temperatures. The number of eggs laid by this pest of conifers is $50 \%$ greater at $77^{\circ} \mathrm{F}\left(25^{\circ} \mathrm{C}\right)$ than at $59^{\circ} \mathrm{F}\left(15^{\circ} \mathrm{C}\right)$ (Regniere 1983). In addition, higher temperatures can shift the timing of reproduction in spruce
TABLE 2. Examples of how increasing temperatures affect arthropod species and arthropod-related systems

\begin{tabular}{ll}
\hline \hline Increasing atmospheric carbon dioxide leads to: & Reference \\
\hline Increasing . . & \\
Northward migration & Parmesan 2006 \\
Migration up elevation gradients & Epstein et al. 1998 \\
Insect developmental rates and oviposition & Regniere 1983 \\
Potential for insect outbreaks & Bale et al. 2002 \\
Invasive species introductions & Dukes and Mooney 1999 \\
Insect extinctions & Thomas et al. 2004 \\
Occurrence of human and animal diseases & Juliano and Lounibos 2005; Patz et al. 2003 \\
Decreasing ... & \\
Effectiveness of insect biocontrol by fungi & Stacy and Fellowes 2002 \\
Reliability of economic threshold levels & Predicted in this paper \\
Insect diversity in ecosystems & Erasmus et al. 2002 \\
Parasitism & Hance et al. 2007; Fleming and Volney 1995 \\
\hline
\end{tabular}

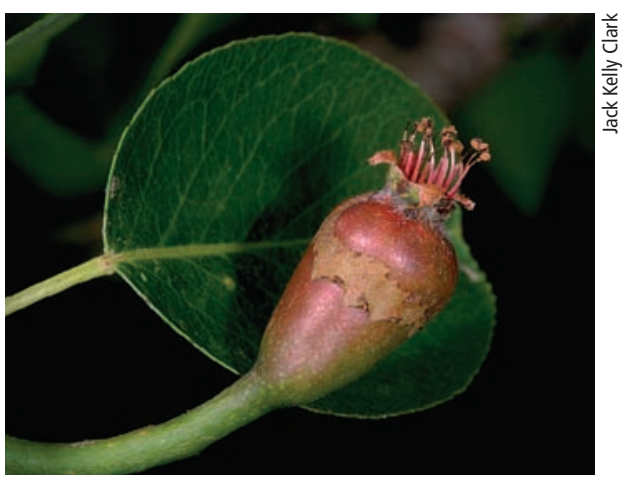

In a warmer environment, frost may be eliminated entirely in some regions, allowing certain insect pests to breed year-round. Above, frost damage to pear. 
budworms so that they may no longer be affected by the parasitoids that usually keep populations down (Fleming and Volney 1995).

Thus, the potential for damaging insect pest outbreaks can be expected to increase as temperatures climb. These outbreaks can lead to substantial ecosystemwide changes in carbon and nitrogen cycling, biomass decomposition and energy flows (Haack and Byler 1993). For example, outbreaks that lead to defoliation or premature leaf drop by plants would change the typical nutritional composition of leaf litter, thereby affecting the success of organisms that decompose decaying biomass. The longterm effects of changes at such fundamental levels are difficult to predict with the available research knowledge.

Another logical outcome of increasing temperatures is an increase in the occurrence and intensity of forest fires. In some cases, particularly when higher temperatures occur along with droughts, trees become more susceptible to insect attack. This effect was seen early in this century in Southern California, with the thousands of acres of trees dead from bark beetle attacks fueling huge forest fires. Some species are attracted to fire-damaged trees, and these insects can be expected to reach exceptional populations if their food resources continue to increase.

\section{Preparing for climate change}

Modifying IPM practices. IPM is the most widely used strategy for insect control in California. This approach generally integrates biological controls (predators, parasites and pathogens), chemical controls (pesticides) and cultural controls (such as resistant crop varieties and planting times) to reduce insects below the population threshold that will cause economic losses. Most researchers and growers try to design IPM programs that maximize economic returns and sustainability while minimizing potential environmental impacts (Trumble 1998). This strategy is based on extensive knowledge of just how many insects can be tolerated before yield losses occur. Researchers and growers have designed and field-tested these programs over many years.

Unfortunately, we predict that scientists and growers will need to mod-

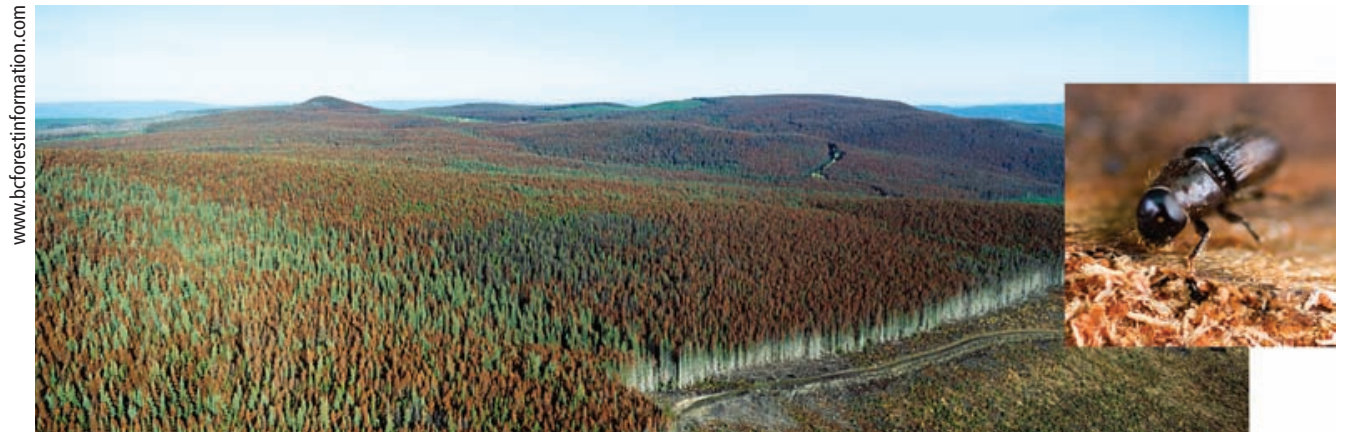

The mountain pine beetle (inset) has dramatically increased its range over the past 15 years, causing extensive damage to British Columbian pine forests (shown); in recent years, it has spread east across the Rocky Mountains.

ify many of these carefully constructed IPM programs to address several important effects of increasing temperature. Because insect development is more rapid at higher temperatures, populations will develop faster and crop damage will occur more rapidly than currently expected. For example, treatment thresholds based on insects per plant will need to be reduced to prevent unacceptable losses. Those IPM programs that rely on degreeday models may need only minimal modification, unless the control strategies include biological control agents. Reports are already available that even the relatively modest increases in temperature that have occurred to date can reduce the effectiveness of insect pathogens (Stacy and Fellowes 2002). In some cases, increasing temperatures can greatly reduce the pest suppression provided by parasites (Hance et al. 2007). These differences between the thermal tolerances of the host and parasitoid can lead to temporal or geographical separation, resulting in pest outbreaks. For example, the fly Drosophila simulans is a suitable host for the wasp Leptopilina heterotoma at temperatures between $64^{\circ} \mathrm{F}$ and $72^{\circ} \mathrm{F}\left(18^{\circ} \mathrm{C}\right.$ and $22^{\circ} \mathrm{C}$ ), but becomes a poor host at $79^{\circ} \mathrm{F}\left(26^{\circ} \mathrm{C}\right)$ (Ris et al. 2004).

In addition, increasing temperatures will likely favor insects with multiple generations each year over those with only a single generation (Bale et al. 2002). Due to the increased developmental rate at higher temperatures, such species could add even more generations and so could potentially achieve much higher numbers by the end of the season. A maximum effect can be expected in those regions where increasing temperatures will entirely eliminate frosts, allowing such insects to breed throughout the year. This will permit a variety of new tropical and subtropical insects to expand into these areas. The effects of such diversity changes on our natural, agricultural and urban ecosystems will probably be profound.

Vectors of human pathogens. In particular, most scientists expect that the recent and predicted increases in temperature will have a major impact on medically important insects such as mosquitoes (Juliano and Lounibos 2005). According to the World Health Organization, the expected climate changes will affect insect-borne diseases such as dengue fever and malaria by increasing insect ranges, reproductive rates and biting rates (Patz et al. 2003). In the case of dengue fever, warmer water temperatures at breeding sites reduce the size of emerging adult mosquitoes that subsequently must blood-feed more frequently to develop their eggs.

Also, the infectious agents that cycle through insects are quite susceptible to even subtle temperature variations. The development of the dengue virus inside the mosquito also shortens with higher temperatures, increasing the proportion of mosquitoes that become infectious at a given time. Higher temperatures have also increased the geographic range of the malarial parasite Plasmodium falciparum. This parasite is generally limited to the tropics and subtropics because it requires an average temperature above $64^{\circ} \mathrm{F}\left(16^{\circ} \mathrm{C}\right)$ to develop. In the past 5 years, temperature increases have extended the range of malaria to elevated urban areas in Africa that had been free of the disease through recorded history (Epstein et al. 
1998). Similarly, much larger portions of the United States now exceed the $64^{\circ} \mathrm{F}$ $\left(16^{\circ} \mathrm{C}\right)$ development threshold, making the important work of mosquito control districts even more critical.

\section{Increased research needs}

Researchers will be hard-pressed to deal with the combined effects of climate change. The capabilities of California's agricultural research community will be stretched by changes in pest species composition and developmental rates, the need to modify IPM strategies, the desirability of introducing new biocontrol agents against invasive species, changes in plant resistance and nitrogen use, and the need for new drought-resistant crop cultivars as well as new cropping systems. In addition, substantial research will be needed to guide management efforts to maintain the functionality of natural systems, given the expected northward movement of plant and animal species, the appearance of new invasive and nonnative species, and the likely ecosystemwide changes in carbon and nitrogen cycling, biomass decomposition and energy flow.

At the same time, human populations in California and the rest of the world are rapidly increasing. Most people live in urban settings and, not surprisingly, do not always have an appreciation for the needs of natural and agricultural ecosystems. In addition, population growth has created exceptional demands for energy, land and water in California, in turn causing conflicts with growers and those who manage protected lands. Unfortunately, this is occurring at a time when we are discovering that reducing costs by outsourcing our food production to other countries does not always produce a safe and nutritious product (Martin and Palmer 2007). The recent discovery that imported eggs, fish and many other food products can contain dangerous levels of melanine serves as an excellent example. The need for additional research to help predict the long-term effects of climate change on agricultural systems is of vital importance to California and the world.

\section{References}

Awmack CS, Harrington R, Leather SR. 1997. Host plant effects on performance of the aphid Aulacorthum solani (Kalt.) (Homoptera: Aphididae) at ambient and elevated $\mathrm{CO}_{2}$. Global Change Biol 3:545-59.

Bale JS, Masters GJ, Hodkinson ID, et al. 2002. Herbivory in global climate change research: Direct effects of rising temperature on insect herbivores. Global Change Biol 8:1-16

Bezemer TM, Jones TH, Knight KJ. 1999. Long term effects of elevated $\mathrm{CO}_{2}$ and temperature on populations of peach aphid Myzus persicae and its parasitoid Aphidium matricariae. Oecologia (Berl.) 116:128-35.

Chen F, Ge F, Parajulee MN. 2005. Impact of elevated $\mathrm{CO}_{2}$ on tritrophic interaction of Gossypium hirsutum Aphis gossypii and Leis axyridis. Environ Entomol 34:37-46.

Coviella C, Morgan DJW, Trumble JT. 2000. Interactions of elevated $\mathrm{CO}_{2}$ and nitrogen fertilization: Effects on the production of Bacillus thuringiensis toxins in transgenic plants. Environ Entomol 29:781-7.

Coviella C, Stipanovic RD, Trumble JT. 2002. Plant allocation to defensive compounds: Interactions between elevated $\mathrm{CO}_{2}$ and nitrogen in transgenic cotton plants. Exp Bot 53:323-31.

Coviella C, Trumble JT. 1999. Elevated atmospheric $\mathrm{CO}_{2}$ and insect-plant interactions: Implications for insect conservation. Conserv Biol 13:700-12.

Coviella C, Trumble JT. 2000. Effect of elevated atmospheric carbon dioxide on the use of foliar application of Bacillus thuringiensis. Biocontrol 45:325-36.

Dukes JS, Mooney HA. 1999. Does global change increase the success of biological invaders? Trends Ecol Evol 14:135-9.

Elias SA. 1994. Quaternary Insects and Their Environments. Washington, DC: Smithsonian Inst Pr. 284 p.

Epstein PR, Diaz HF, Elias S, et al. 1998. Biological and physical signs of climate change: Focus on mosquitoborne diseases. Bull Am Meteorol Soc 79:409-17.

Erasmus BFN, van Jaarsveld AS, Chown S, et al. 2002 Vulnerability of South African animal taxa to climate change. Global Change Biol 8:679-93

Fleming RA, Volney WJA. 1995. Effects of climate change on insect defoliator population processes in Canada boreal forest - some plausible scenarios. Water Air Soil Poll 82:445-54.

Haack RA, Byler JW. 1993. Insects and pathogens: Regulators of forest ecosystems. J Forest 1:32-7.

Hadley Centre. 2007. Climate Change. www. metoffice.gov.uk/climatechange. Exeter, Devon, UK.

Hance T, van Baaren J, Vernon P, Boivin G. 2007. Impact of extreme temperatures on parasitoids in a climate change perspective. Ann Rev Entomol 52:107-26.
Hollinger DY. 1987. Gas exchange and dry matter allocation responses to elevation of atmospheric $\mathrm{CO}_{2}$ concentration in seedlings of three tree species. Tree Physiol 3:193-202.

[IPCC] Intergovernmental Panel on Climate Change. 2007. Climate change 2007: Synthesis approach. www.ipcc.ch/pdf/assessment-report/ar4/syr/ar4_syr_ spm.pdf.

Juliano SA, Lounibos LP. 2005. Ecology of invasive mosquitoes: Effects on resident species and on human health. Ecol Letters 8:558-74.

LaMarche VC, Grabyll DA, Fritts HC, Rose MR. 1984 Increasing atmospheric carbon dioxide: Tree ring evidence for growth enhancement in natural vegetation. Science 225:1019-21.

Liu D, Trumble JT. 2007. Comparative fitness of invasive and native populations of the potato psyllid (Bactericera cockerelli). Entomol Exp Appl 123:35-42.

Logan JA, Powell JA. 2001. Ghost forests, global warming and the mountain pine beetle. Am Entomol 47:160-73.

Martin A, Palmer G. 2007. China not sole source of dubious food. New York Times, July 12.

Osbrink WLA, Trumble JT, Wagner RE. 1987. Host suitability of Phaseolus lunata for Trichoplusia ni (Lepidoptera: Noctuidae) in controlled carbon dioxide atmospheres. Environ Entomol 16:639-44.

Parmesan C. 2006. Ecological and evolutionary responses to recent climate change. Ann Rev Ecol Evol Sys 37:637-69.

Patz JA, Githeko AK, McCarty JP, et al. 2003. Climate change and infectious diseases. In: McMichael AJ, Campbell-Lendrum DH, Corvalan CF (eds.). Climate Change and Human Health: Risks and Responses. Geneva, Switz.: World Health Organization. p 103-32.

Regniere J. 1983. An oviposition model of the spruce budworm, Choristoneura fumiferana (Lepidoptera: Tortricidae). Can Entomol 115:1371-82.

Ris N, Allemand R, Fouillet P, Fleury F. 2004. The joint effect of temperature and host species induce complex genotype-by-environment interactions in the larval parasitoid of Drosophila, Leptopilina heterotoma (Hymenoptera: Figitidae). Oikos 106:451-6.

Roth SK, Lindroth RL. 1995. Elevated atmospheric $\mathrm{CO}_{2}$ : Effects on phytochemistry, insect performance and insect-parasitoid interactions. Global Change Biol 1:173-82.

Stacey DA, Fellowes MDE. 2002. Influence of temperature on pea aphid Acyrthosiphon pisum (Hemiptera: Aphididae) resistance to natural enemy attack. Bull Entomol Res 92:351-7.

Thomas CD, Cameron A, Green RE, et al. 2004. Extinction risk from climate change. Nature 427:145-8.

Trumble JT. 1998. IPM: Overcoming conflicts in adoption. Integr Pest Manage Rev 3:195-207.
J.T. Trumble is Professor, and C.D. Butler is Graduate Student, Department of Entomology, UC Riverside. We gratefully acknowledge the help of Greg Kund in preparing the figures. The reviews by Kristen Hladun, Mary Sorensen, Greg Kund and William Carson improved this manuscript. We appreciate the input of several anonymous reviewers and the editors of California Agriculture. 